\title{
ISOLASI SQUALEN DARI ASAM LEMAK SAWIT DISTILAT (ALSD)
}

\section{(ISOLATION OF SQUALENE FROM PALM FATTY ACID DISTILLATE)}

\author{
Eka Nuryanto ${ }^{1}$, Justaman A Karo Karo ${ }^{2}$, Eddiyanto ${ }^{3}$, A. Gazali S. Sinaga ${ }^{4}$, dan \\ Retno Widiastuti ${ }^{5}$ \\ ${ }^{1,4)}$ Pusat Penelitian Kelapa Sawit. JI. B. Katamso No. 51 Medan \\ ${ }^{2)}$ Balai Riset Dan Standardisasi Industri Medan. Jl. Sisingamangaraja No.24, Medan \\ ${ }^{3,5)}$ Universitas Negeri Medan. Jl. Willem Iskandar Pasar V Medan Estate Medan \\ E-mail: eka_nuryanto_ppks@yahoo.com
}

Received: 16 Juni 2016 ; revised: 29 Juli 2016; accepted: 25 agustus 2016;

\begin{abstract}
ABSTRAK
Asam lemak sawit distilat (ALSD) merupakan hasil samping dari pabrik minyak goreng kelapa sawit dan mengandung squalen sekitar $1 \%$. Squalen dapat digunakan sebagai bahan dasar dalam industri kosmetika dan obat-obatan. Pada penelitian ini squalen diperoleh dari saponifikasi ALSD yang dilanjutkan dengan ekstraksi dan pencucian sehingga diperoleh cairan berwarna kuning yang kemudian dianalisis menggunakan Gas Chromatography (GC) dan Fourier Transform Infra Red (FTIR). Pemurnian cairan ini menggunakan kromatografi kolom dengan fase gerak heksana dan fase diam silika gel tipe 60 . Hasil penelitian menunjukkan bahwa karakteristik ALSD adalah kadar air 0,30\%, asam lemak bebas (ALB) 90,56 \%, bahan tak tersabunkan $9,03 \%$, bilangan penyabunan $223,23 \mathrm{mg} \mathrm{KOH} / \mathrm{g}$, bilangan peroksida $25,86 \mathrm{mek} / \mathrm{kg}$. Sementara komposisi asam lemak di dalam ALSD adalah asam laurat (C:12) 0,19\%, asam miristat (C:14) 1,03\%, asam palmitat (C:16) 48,59\%, asam stearat (C:18) 3,71\%, asam oleat (C:18:1) 37,74\%, asam linoleat (C:18:2) 7,97 \%, dan asam linolenat $(C: 18: 3)$ 0,21 \%. Sementara itu kandungan squalen di dalam bahan tak tersabunkan adalah 139.000 ppm. Squalen yang diperoleh masih tidak murni terbukti dengan hasil analisis FTIR munculnya puncak pada bilangan gelombang $1700 \mathrm{~cm}^{-1}$ yang menunjukkan gugus $\mathrm{C}=\mathrm{O}$ karbonil. Pemurnian dengan kromatografi kolom dapat memurnikan squalen hingga konsentrasi 239.000 ppm.
\end{abstract}

Kata kunci : Minyak kelapa sawit, Asam lemak sawit, Squalen

\section{ABSTRACT}

Palm fatty acid distillate (PFAD) is a by product of palm oil refinery and contains approximately $1 \%$ of squalene. Squalene can be used as a basic material in the cosmetic and medicine industries. In this study, squalene was isolated from PFAD by using saponification method and then extracted and washed to obtained a yellow liquid and analyzed by using gas chromatography (GC) and fourier transform infra red (FTIR). The liquid purification was carried out using column chromatography with hexane (mobile phase) and silica gel 60 (stationary phase). The results showed that the characteristics PFAD is $0.30 \%$ water content, free fatty acids $90.56 \%$, unsaponifible matter $9.03 \%$, saponification value $223.23 \mathrm{mg} \mathrm{KOH} / \mathrm{g}$, and peroxide value $25.86 \mathrm{meq} / \mathrm{Kg}$. While the composition of fatty acids in PFAD is lauric acid (C:12) 0.19\%, myristic acid (C:14) 1.03\%, palmitic acid (C:16) 48.59\%, stearic acid (C:18) 3.71\%, oleic acid (C:18:1) 37.74\%, the linoleic acid (C:18:2) 7.97\%, and linolenic acid (C:18:3) $0.21 \%$. The content of squalene in the unsaponified material was $139,000 \mathrm{ppm}$. Squalene obtained was not pure as shown by the results of FTIR analysis, in which of the peak at wave number $1700 \mathrm{~cm}-1$ indicates that the $C=O$ carbonyl group. Purification by using column chromatography could purify squalene up to concentration of 239,000 ppm.

Key words : Palm oil, Palm fatty acid, Squalene

\section{PENDAHULUAN}

Asam lemak sawit distilat (ALSD) merupakan hasil samping dari pabrik minyak goreng kelapa sawit. ALSD ini merupakan salah satu sumber squalen yang belum dimanfaatkan. Posada et al. (2007), melaporkan bahwa ALSD mengandung squalen yang tinggi hingga $1,03 \%$ w/w. Sekitar 3,66 ton ALSD dapat dihasilkan dari 100 ton minyak kelapa sawit mentah/crude palm oil (CPO) yang diolah menjadi minyak goreng (Norhidayah et al. 
2012). Pemanfaatan ALSD di bidang oleokimia telah banyak dikembangkan (Cheah et al. 2010). Sementara menurut Tapanwong dan Punsuvon (2011) ALSD banyak digunakan sebagai bahan baku pada industri sabun, biodiesel dan pakan ternak.

Squalen $\left(\mathrm{C}_{30} \mathrm{H}_{50}\right)$ termasuk senyawa polihidrokarbon tidak jenuh dan banyak ditemukan dalam minyak hati ikan hiu hitam genus Zameus. Squalen mempunyai berat molekul 410,7 dan mempunyai nama kimia 2,6,10,15,19,23-hexamethyl-2,6,10,14,18,22-

teracosahexaene. Keistimewaan dari squalen adalah daya uapnya yang rendah, titik bekunya di bawah $-45{ }^{\circ} \mathrm{C}$ dan tetap bening pada suhu $20{ }^{\circ} \mathrm{C}$ serta mudah menangkap dan melepaskan oksigen (Spanova and Daum 2011).

Squalen sering digunakan secara klinis dalam dosis harian seperti detoksifikasi, antioksidan, agen bakterisida dan fungisida, agen antistatik dan pelembab pada sediaan kosmetik dan farmasi, dan pada suhu rendah dapat berfungsi sebagai pelicin (Norhidayah et al. 2012). Beberapa penelitian melaporkan bahwa mengkonsumsi squalen dalam jumlah yang banyak tidak meningkatkan kadar triasilgliserol dan kolesterol di dalam darah (Strandberg et al. 1990), bahkan menurut Gabas-Rivera et al. (2014) mengatakan squalen dapat menurunkan level oksidasi di dalam tubuh dan meningkatkan kadar high density lipoprotein (HDL).

Squalen dapat digunakan sebagai bahan dasar dalam industri kosmetika dan obat-obatan untuk perawatan kulit dan sebagai antioksidan (Amarowicz 2009). Untuk kosmetika digunakan dalam krim terutama krim nutrisi dan krim medis, dan juga pada kosmetik jenis lainnya termasuk milky lotion, face lotion, lipstick, foundation dan powder. Di bidang pengobatan, squalen diaplikasikan dalam bentuk salep (ointments) dan suppositories karena mudah diabsorbsi ke dalam kulit. Menurut Gunes (2013) dan Kelly (1999), squalen berperan sebagai antioksidan dan agensia anti kanker, selain itu juga dapat dipergunakan untuk detoksifikasi. Norhidayah, et al. (2012) telah mengisolasi squalen dari ALSD dengan menggunakan metode Supercritical Fluid Extraction (SFE). Isolasi dengan metode SFE ini menggunakan tekanan yang sangat tinggi, yaitu 200 bar sampai dengan 400 bar dengan squalen yang dihasilkan 418,31 ppm. Pada penelitian ini dilakukan isolasi squalen dari ALSD dengan metode saponifikasi yang dilakukan pada tekanan atmosfir.

\section{BAHAN DAN METODE}

\section{Bahan}

Bahan-bahan yang digunakan pada penelitian ini adalah ALSD sebagai bahan baku, etanol, $\mathrm{KOH}$, heksan, standar squalen, silika gel tipe 60, dan bahan-bahan kimia lainnya. Alat-alat yang digunakan adalah gas chromatography (GC), high performance liquid chromatography (HPLC), fourier transform infra red (FTIR), kolom kromatografi, dan alat-alat gelas.

\section{Metode}

Karakterisasi ALSD meliputi kadar asam lemak bebas, komposisi asam lemak bebas, bilangan peroksida, bilangan penyabunan, dan kadar air sesuai metode AOCS (Anonim 2011).

Saponifikasi ALSD dilakukan dengan menggunakan larutan $\mathrm{KOH} 25 \%$ di dalam etanol $96 \%$. 10 g ALSD disabunkan dengan 9,2 mL $\mathrm{KOH}$ etanolik $25 \%$ di dalam $88 \mathrm{~mL}$ etanol $96 \%$ pada suhu $50{ }^{\circ} \mathrm{C}$ sampai dengan $55^{\circ} \mathrm{C}$ selama 30 menit. Campuran reaksi kemudian diekstrak menggunakan heksana dan dicuci dengan aquades. Fraksi heksana dikeringkan dengan menggunakan evaporasi vakum pada suhu $50{ }^{\circ} \mathrm{C}$. Sampai tahap ini akan diperoleh cairan berwarna kuning tetapi tidak berminyak dan akan dianalisis menggunakan gas chromatography (GC) dengan metode derivatisasi menurut Mendez, dkk (2003).

Fraksi tidak tersabunkan kemudian dimurnikan dengan kromatografi kolom dengan fase gerak heksana dan fase diam silika gel tipe 60 (size $60 \AA$, 70-230 mesh, 63-200 $\mu \mathrm{m}$ ). Hasil pemisahan dianalisis kandungan gugus fungsinya dengan FTIR. Sementara itu, pengukuran kandungan squalen dilakukan dengan metode HPLC (Schneider 2013).

\section{HASIL DAN PEMBAHASAN}

Asam lemak sawit distilat (ALSD) yang digunakan pada penelitian ini adalah merupakan hasil samping dari pabrik minyak goreng kelapa sawit yang berada di Sumatra Utara. Pada suhu kamar ALSD ini berbentuk padat dan berwarna kecoklatan dengan karakteristik sebagai berikut: kadar air 0,30\%, asam lemak bebas (ALB) $90,56 \%$, bahan tak tersabunkan $9,03 \%$, bilangan penyabunan 223,23 $\mathrm{mg} \mathrm{KOH} / \mathrm{g}$, bilangan peroksida 25,86 mek/kg. Kandungan ALB dari ALSD ini sangat tinggi mencapai di atas $90 \%$, hal ini dapat dipahami karena ALSD merupakan destilat hasil pemisahan asam lemak yang terdapat di dalam crude palm oil (CPO) dengan proses distilasi pada suhu $280{ }^{\circ} \mathrm{C}$ dengan tekanan vakum (Gapor 2010).

Metre and Nath (2015) melaporkan kandungan ALB di dalam ALSD adalah 85\% sampai dengan 95\%. Sementara itu, hasil analisis dengan GC memperlihatkan bahwa 
komposisi asam lemak di dalam ALSD adalah asam laurat (C:12) 0,19\%, asam miristat (C:14) $1,03 \%$, asam palmitat (C:16) $48,59 \%$, asam stearat (C:18) 3,71\%, asam oleat (C:18:1) $37,74 \%$, asam linoleat (C:18:2) 7,97\%, dan asam linolenat (C:18:3) 0,21\%.

Proses saponifikasi terhadap ALSD dilakukan dengan menggunakan larutan $\mathrm{KOH}$ dengan menggunakan pelarut etanol kemudian diekstraksi oleh heksan. Hasil proses saponifikasi ini memberikan produk squalen kasar dengan konsentrasi 139.000 ppm. Analisis FTIR squalen kasar dan standar diplotkan gelombang yang sama (Gambar 1).

Analisa FTIR ini dapat digunakan untuk memperoleh informasi gugus-gugus fungsi yang terdapat di dalam suatu struktur senyawa kimia, di samping untuk membedakan secara kualitatif senyawa kimia yang mempunyai gugus fungsi yang berbeda. Pada Gambar 1 terlihat bahwa sebagian besar puncak-puncak gugus fungsi yang ada di squalen hasil ekstraksi dari ALSD berimpit dengan puncak-puncak dari standar squalen. Hanya ada satu puncak dari squalen ALSD yang berbeda yaitu pada bilangan gelombang $1742 \mathrm{~cm}^{-1}$. Puncak ini menunjukkan masih adanya gugus karbonil yang terdapat di dalam squalen ALSD. Pada Tabel 1 disajikan puncak-puncak yang muncul di dalam spektrum FTIR dari standar squalen dan squalen ALSD (Gambar 1) dan squalen hasil penelitian Chun et al. (2013).

Dari Gambar 1 dan Tabel 1 terlihat bahwa ada satu puncak yang muncul di bilangan gelombang $1744 \mathrm{~cm}^{-1}$ dari squalen ALSD yang tidak muncul pada standar squalen maupun squalen menurut Chun et al. (2013). Puncak yang muncul pada bilangan gelombang tersebut menunjukkan adanya gugus $\mathrm{C}=\mathrm{O}$ karbonil yang masih terdapat di dalam squalen ALSD. Hal ini mengindikasikan bahwa squalen yang diperoleh masih ada pengotor senyawa bergugus $\mathrm{C}=\mathrm{O}$ yang berasal dari asam lemak bebas. Sementara seharusnya di dalam squalen tidak terdapat gugus $\mathrm{C}=\mathrm{O}$ seperti ditunjukkan oleh struktur squalen pada Gambar 2 (Chun et al. 2013).

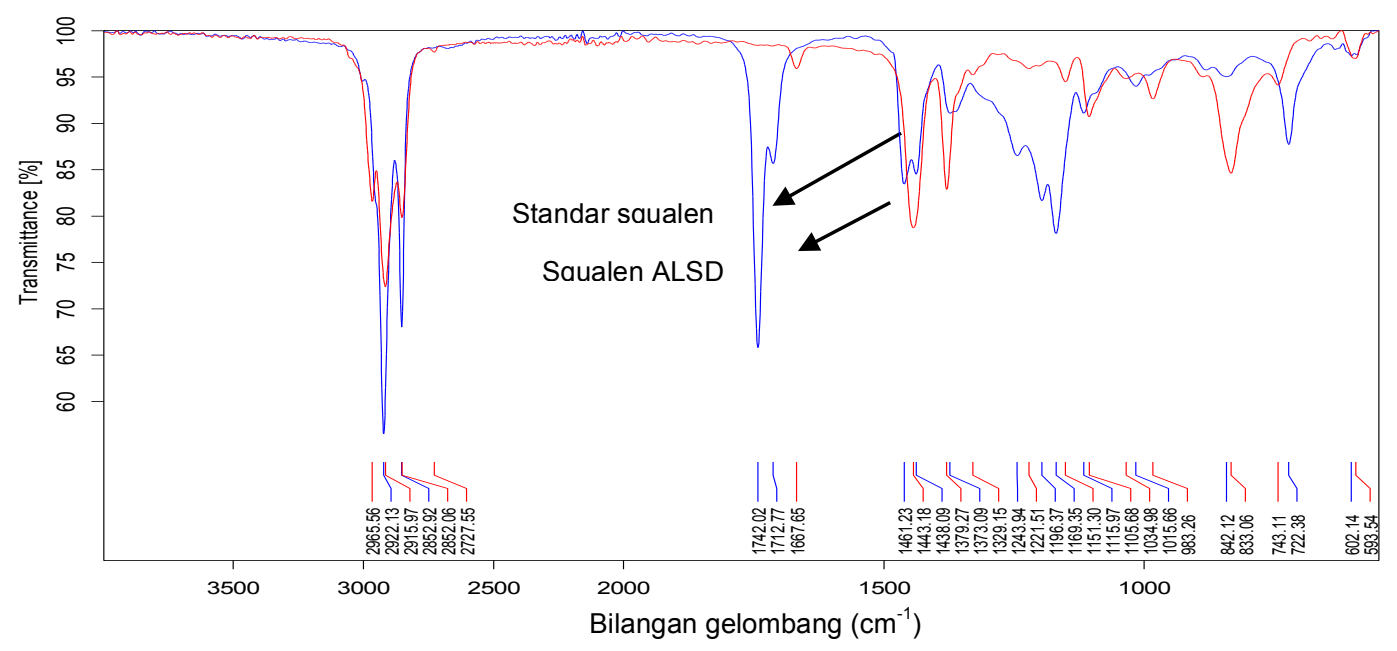

Gambar 1. Spektrum FTIR standar squalen dan squalen dari ALSD

Tabel 1. Puncak-puncak yang muncul pada spektrum FTIR dari standar squalen, squalen ALSD, dan squalen hasil analisis Chun et al.*

\begin{tabular}{|c|c|c|c|}
\hline \multirow{2}{*}{ Vibrasi } & \multicolumn{3}{|c|}{ Bilangan Gelombang $\mathrm{Cm}^{-1}$} \\
\hline & Standar Squalen & Squalen kasar & Squalen* \\
\hline $\mathrm{CH} 3$ stretch & $2965 ; 2915$ & $2957 ; 2922$ & $2911-3024$ \\
\hline $\mathrm{CH} 3$ deformation & $1379 ; 1329$ & 1378 & $1254-1460$ \\
\hline $\mathrm{CH} 3$ rock & $\begin{array}{l}\text { 983; 1034; 1105; 1151; } \\
1221\end{array}$ & $1034 ; 1107 ; 1169$ & $943-1228$ \\
\hline $\mathrm{CH} 2$ stretch & $2852 ; 2727$ & 2854 & 2904-2988 \\
\hline $\mathrm{CH} 2$ deformation & 1443 & 1452 & $1428-1460$ \\
\hline $\mathrm{CH} 2$ rock & $\begin{array}{l}743 ; \quad 833 ; \quad 983 ; \quad 1034 ; \\
1105\end{array}$ & 833 & $730-1207$ \\
\hline $\mathrm{C}=\mathrm{C}$ stretch & 1667 & 1667 & $1668-1679$ \\
\hline C-C stretch & $743 ; 833$ & $724 ; 833$ & $730-1379$ \\
\hline $\mathrm{C}=\mathrm{C}-$ & 593 & 593 & $319-592$ \\
\hline $\mathrm{C}=\mathrm{O}$ & - & 1744 & - \\
\hline
\end{tabular}




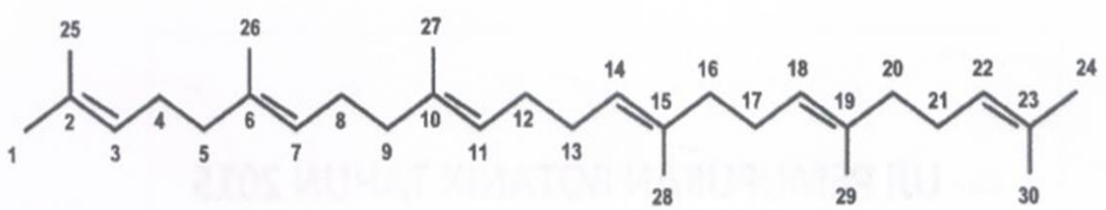

Gambar 2. Struktur kimia squalen

Berdasarkan hasil identifikasi menunjukkan bahwa squalen dari ALSD masih tercampur dengan asam lemak bebas, maka dilakukan pemurnian terhadap squalen tersebut menggunakan kromatografi kolom. Kromatografi kolom adalah metode yang digunakan untuk memurnikan bahan kimia tunggal dari campurannya.

Pada proses pemurnian dengan metode ini menggunakan dua fase, yaitu fase gerak dan fase diam. Komponen-komponen tunggal tertahan oleh fase diam secara berbeda satu sama lain pada saat campuran tersebut bergerak bersama eluen dengan laju yang berbeda melalui kolom. Di akhir kolom, campuran komponen tersebut terelusi satu per satu. Selama keseluruhan proses kromatografi, eluen dikumpulkan sesuai fraksi-fraksinya.

Pada penelitian ini digunakan fase diam silica gel $G$ tipe 60 dan fase gerak n-heksana. Hasil pemurnian squalen kasar dengan metode kromatografi kolom diperoleh 16 fraksi. Pada Tabel 2 di bawah ini disajikan berat masingmasing fraksi setelah dihilangkan pelarutnya. Fraksi 16 merupakan fraksi terbanyak dengan berat akhir $0,1856 \mathrm{~g}$ dan fraksi 1 adalah fraksi terendah dengan berat akhir 0,0088 g. Hasil setiap fraksi kemudian dianalisa dengan menggunakan spektroskopi FTIR.

Pada Gambar 3 dan 4 disajikan spektrum FTIR squalen hasil pemisahan dengan kromatografi kolom untuk fraksi 1 dan 2. Pada Gambar 3 dan 4 terlihat bahwa pada fraksi 1 dan 2 gugus fungsi yang muncul berimpit dengan puncak dari gugus fungsi yang ada di standar squalen. Hal ini mengindikasikan bahwa telah terjadi pemisahan dari squalen ALSD oleh kromatografi kolom.
Tabel 2. Jumlah fraksi dan berat fraksi hasil pemurnian squalen ALSD

\begin{tabular}{cc}
\hline Nama & Berat Akhir (gram) \\
\hline Fraksi 1 & 0,0088 \\
Fraksi 2 & 0,0477 \\
Fraksi 3 & 0,0983 \\
Fraksi 4 & 0,0982 \\
Fraksi 5 & 0,0475 \\
Fraksi 6 & 0,0554 \\
Fraksi 7 & 0,0424 \\
Fraksi 8 & 0,0326 \\
Fraksi 9 & 0,0268 \\
Fraksi 10 & 0,0238 \\
Fraksi 11 & 0,0194 \\
Fraksi 12 & 0,0370 \\
Fraksi 13 & 0,0185 \\
Fraksi 14 & 0,0421 \\
Fraksi 15 & 0,0960 \\
Fraksi 16 & 0,1856 \\
\hline
\end{tabular}

Sementara itu, pada Gambar 5 di bawah ini disajikan spektrum FTIR dari fraksi 3 .

Pada Gambar 5 di atas terlihat bahwa pada fraksi 3 muncul puncak pada bilangan gelombang $1744 \mathrm{~cm}^{-1}$, puncak ini mengindikasikan adanya gugus karbonil ester yang terdapat di dalam senyawa yang ada di fraksi 3. Pada fraksi 4 sampai 16 spektrum FTIRnya juga muncul puncak pada daerah $1700 \mathrm{~cm}^{-1}$. Hal ini menunjukkan bahwa hanya pada fraksi 1 dan 2 diperoleh squalen yang sama dengan standar squalen. 


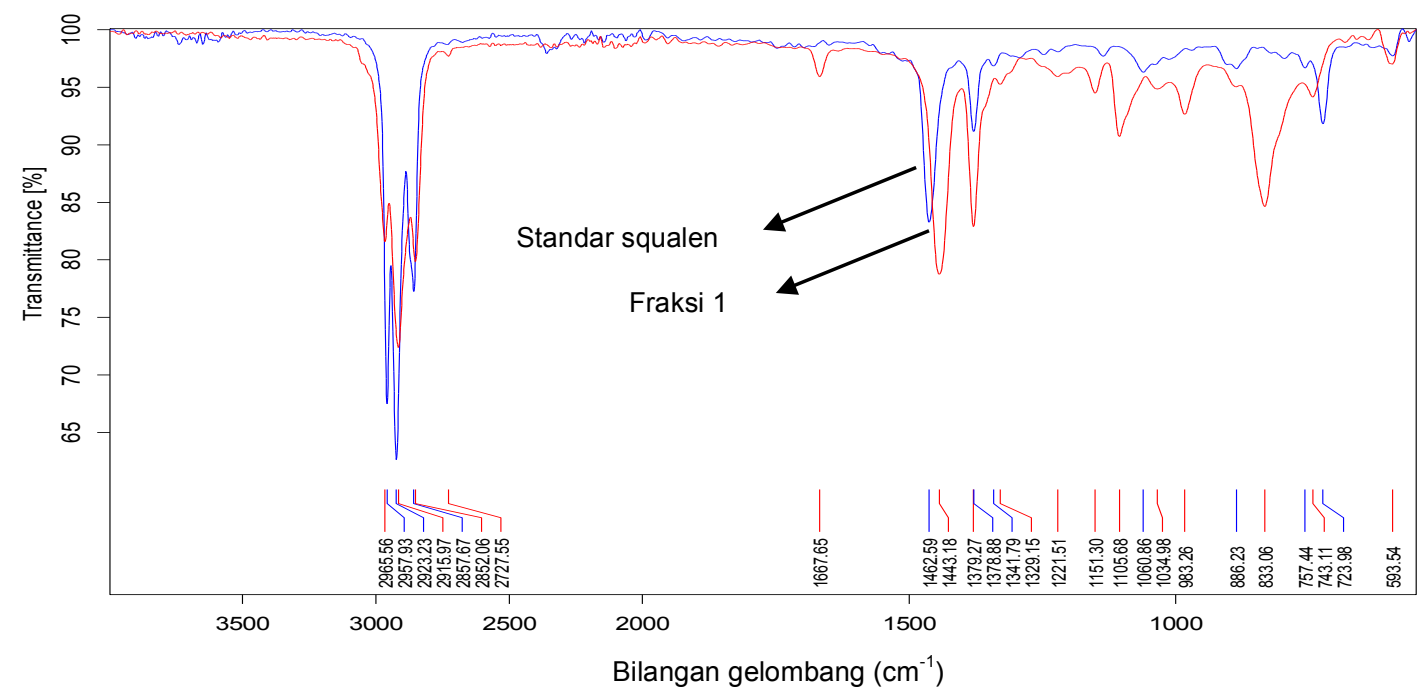

Gambar 3. Spektrum FTIR standar squalen dan fraksi 1

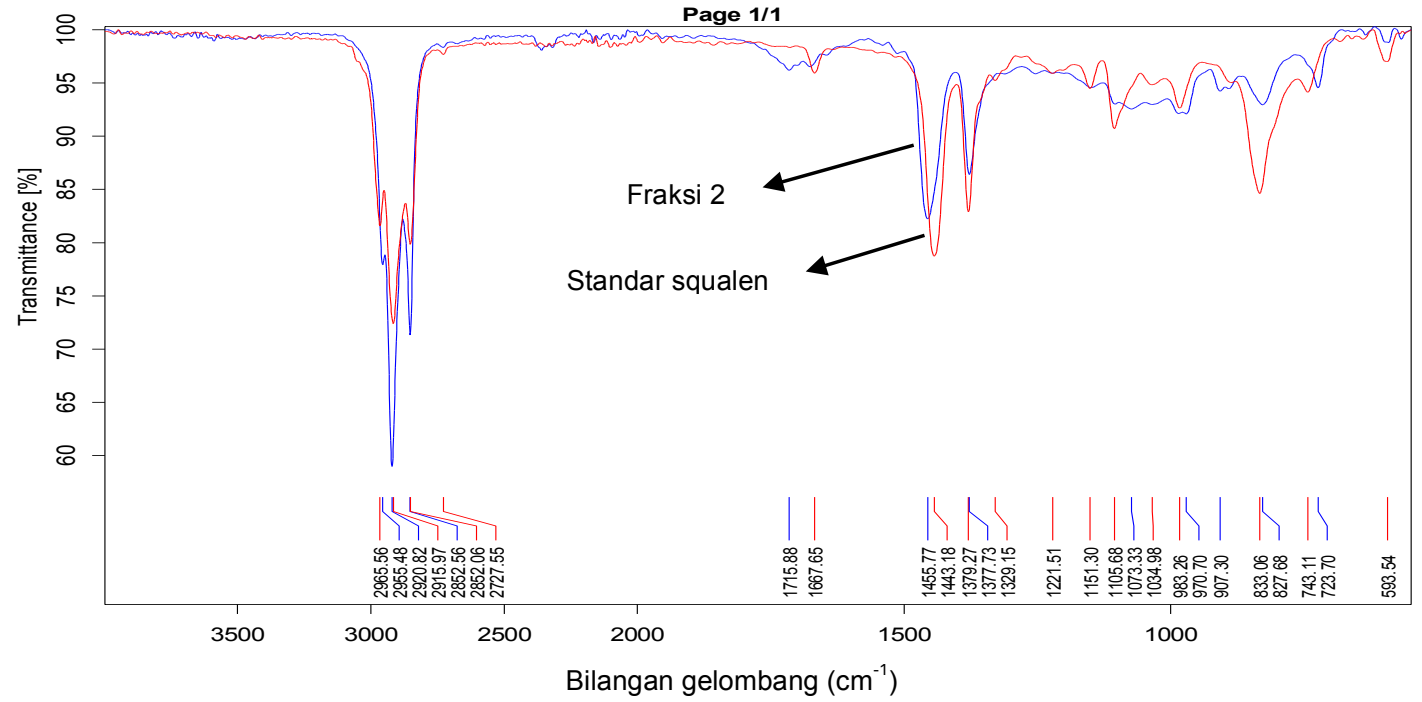

Gambar 4. Spektrum FTIR standar squalen dan fraksi 2

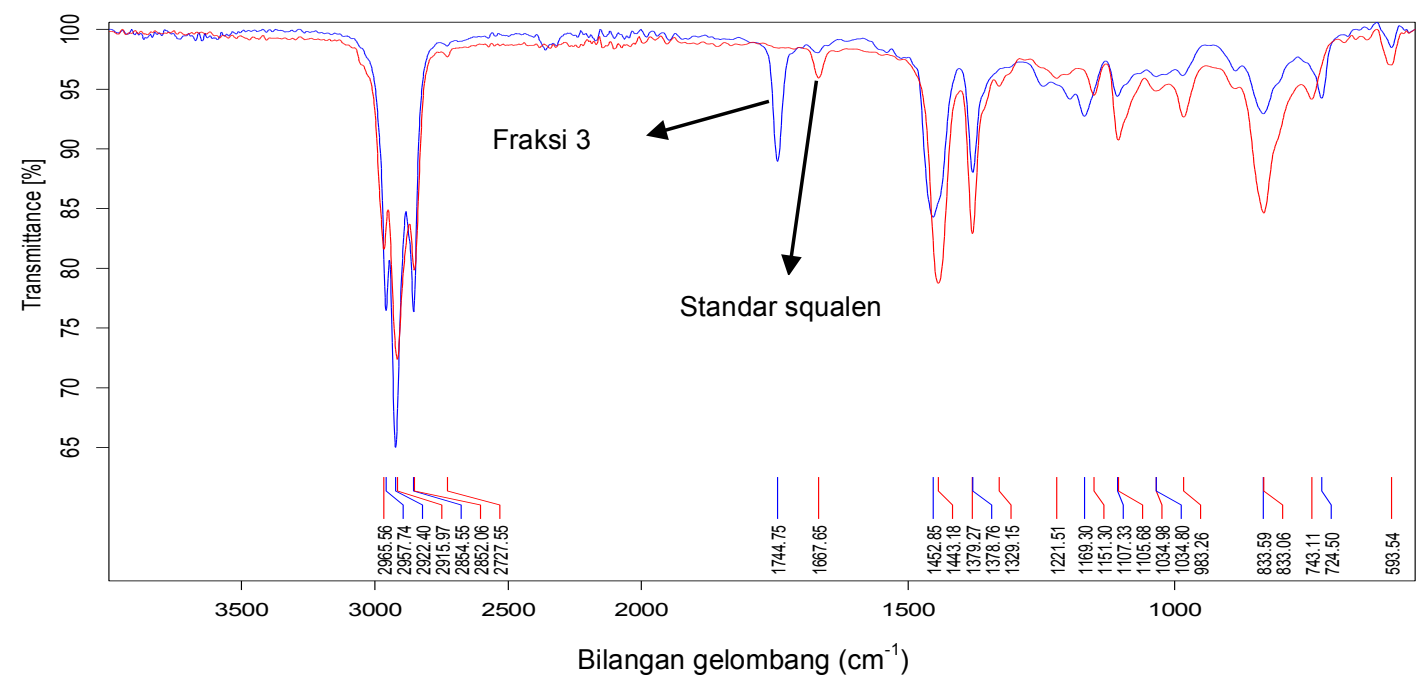

Gambar 5. Spektrum FTIR standar squalen dan fraksi 3 


\section{KESIMPULAN}

Kandungan squalen di dalam bahan tak tersabunkan dari ALSD adalah 139.000 ppm. Squalen yang diperoleh masih tidak murni terbukti dengan hasil analisis FTIR munculnya puncak pada bilangan gelombang $1700 \mathrm{~cm}^{-1}$ yang menunjukkan gugus $\mathrm{C}=\mathrm{O}$ karbonil. Pemurnian dengan kromatografi kolom diperoleh 16 fraksi dimana hanya fraksi 1 dan 2 yang menunjukkan gugus fungsi yang sama dengan standar squalen. Konsentrasi squalen dari ke dua fraksi tersebut mencapai 239.000 ppm.

\section{DAFTAR PUSTAKA}

Amarowicz, R. 2009. Squalene: A natural antioxidant European journal of lipid science and technology 111 (5) : 411412.

Anonim. 2011. Official Methods and Recommended Practices of the AOCS. Sixth Edition, AOCS. Urbana, Illinois USA.

Cheah, K.Y., T.S.Toh, and P.M. Koh. 2010. Palm fatty acid distillate biodiesel. International news on fats, oils, and related materials 21 (5) : 264-266.

Chun, H.J., T.L. Weiss, T.P. Devarenne, and J. Laane. 2013. Vibrational spectra and DFT calculations of squalene. Journal of molecular structure 1032 : 203-206.

Gabás-Rivera, C., C. Barranquero, R. Martínez-Beamonte, , M.A. Navarro, J. Surra, , and J. Osada, 2014. Dietary Squalen Increases High Density Lipoprotein-Cholesterol and Paraoxonase 1 and Decreases Oxidative Stress in Mice. Journal plos one 9 (8) : 1-9.

Gapor Md. Top. 2010. Production and utilization of palm fatty acid distillate (PFAD). Lipid technology 22 (1) : 11-13.

Gunes, F.E. 2013. Medical use of squalene as a natural antioxidant. Journal of Mamara University Institute of health sciences
$3(4)$ : 220-228.

Kelly, G.S. 1999. Squalene and its potential clinical uses. Alternative medicine review 4 (1) : 29-36.

Mendez, E., M. Blanco, A. Laguna and E. Garcia. 2003. Isolation and characterization of a mixture of higher primary aliphatic alcohols of high molecular weight from henequen (Agave furcroydes L.) wax. Revista CENIC ciencias químicas 34 (1) : 3538.

Norhidayah, S., B.S. Baharin, M. Hamed, and I.S.M. Zaidul, 2012. Squalen recovery from palm fatty acid distillate using supercritical fluid extraction. International food research journal 19 (4) : 1661-1667.

Posada, L.R., J. Shi, Y. Kakuda, , and S.J. Xue, 2007. Extraction of Tocotrienols from Palm Fatty Acid Distillates Using Molecular Distillation. Journal separation purification technolog. 57 (2) : 220-229.

Schneider, S. Determination of squalene in virgin olive oil. Agilent Technologies Inc. Aplication Note, Publication Number 5991-2774EN.

Spanova, M and G. Daum. 2011. Squalene biochemistry, molecular biology, process biotechnology, and applications. European journal of lipid science and technology 113 (11) : 1299-1320.

Strandberg, T.E., R.S. Tilvis, , and T.A. Miettinen, 1990. Metabolic variables of cholesterol during squalen feeding humans: comparison with cholestyramine treatment. Journal of lipid research 31 (9) : 1637-1643.

Tapanwong M. and V. Punsuvon 2011. Optimization of wax esters production from palm fatty acid distillate and oleyl alcohol over amberlyst. Journal of environmental science and engineering, 5 : 1427-1434. 